\title{
Short Communication: Population structure and habitat characteristics of Goniothalamus macrophyllus in Bukit Pembarisan forest, West Java, Indonesia
}

\author{
ILHAM ADHY A ${ }^{1,2, \vartheta}$, PUDJI WIDODO ${ }^{2, \vartheta}$, CECEP KUSMANA $^{3}$, EMING SUDIANA ${ }^{2}$, IMAM WIDHIONO ${ }^{2}$, \\ TOTO SUPARTONO ${ }^{1}$ \\ ${ }^{1}$ Faculty of Forestry, Universitas Kuningan. Jl. Tjut Nyak Dhien, Cijoho, Kuningan 45513, West Java, Indonesia. Tel./fax.: +62-232-874824-873696, \\ "email: ilhamadhya@yahoo.co.id \\ ${ }^{2}$ Faculty of Biology, Universitas Jenderal Soedirman. J1. Dr. Soeparno 63, Purwokerto, Banyumas 53122, Central Java, Indonesia. \\ Tel.: +62-281-638794,Fax: +62-281-631700, ${ }^{\text {} e m a i l: ~ p w i d o d o @ u n s o e d . a c . i d ~}$ \\ ${ }^{3}$ Faculty of Forestry, Institut Pertanian Bogor. Jl. Lingkar Akademik, Dramaga, Bogor 16680, West Java, Indonesia
}

Manuscript received: 14 January 2019. Revision accepted: 19 February 2020

\begin{abstract}
Adhya I, Widodo P, Kusmana C, Sudiana E, Widhiono I, Supartono T. 2020. Short Communication: Population structure and habitat characteristics of Goniothalamus macrophyllus in Bukit Pembarisan forest, West Java, Indonesia. Biodiversitas 21: 1130-1135. Goniothalamus macrophyllus (Blume) Hook.f. \& Thomson is a forest species with important medicinal value and widely used by many local communities. Excessive harvesting of this species has led to population decline and may lead to extinction. The aims of this research was to investigate population structure, habitat characteristics and environmental factors affecting local densities of $G$. macrophyllus in Bukit Pembarisan forest, Kuningan District, West Java, Indonesia. Purposive sampling was conducted at 17 locations from November 2017 to March 2018. The result showed that the population structure in the study area was dominated by seedlings ( $95 \%$ of the total number of individuals), followed by saplings $(4 \%)$ and poles $(0.1 \%)$. Seedlings, saplings, and poles were found growing across a wide elevational range (432-1,273 m asl.), at temperatures of $19-25^{\circ} \mathrm{C}$, relative humidity of $80-90 \%$, and soil $\mathrm{pH}$ of 4.61-6.46. The multiple regression analysis showed that soil nitrogen and soil $\mathrm{pH}$ affected seedling density, whereas soil clay content affected pole density. Our findings indicate that G. macrophyllus preferred acidic soils with high nitrogen and high clay content. We, therefore, recommend that future conservation efforts include the maintenance of existing poles, a prohibition on bark harvesting, and encouraging use of the leaves, rather than bark, for medicinal applications among consumers of G. macrophyllus.
\end{abstract}

Keywords: Plant conservation, population density, soil characteristics

\section{INTRODUCTION}

The genus Goniothalamus (Annonaceae family) comprises 50-130 species distributed from Southeast Asia and Malaysia to the northern tropical regions of Australia (Jessup 1986; Saunders 2003; Nakkhuntod et al 2009; Tang et al 2013). Goniothalamus spread in lowland forests and sub-tropical Southeast Asia: western Malesia, Kalimantan (Mat-Salleh 2001; Turner and Saunders 2008), Sumatra (Saunders 2002), Peninsular Malaysia/ Thailand, south of Isthmus of Kra (Saunders 2003; Saunders and Chalermglin 2008), and southern India and Sri Langka (Huber 1985: Mitra 1997). Of these, Goniothalamus macrophyllus (Blume) Hook.f. \& Thomson is a shrub or a small tree up to $8 \mathrm{~m}$ in height. In Southeast Asia, G. macrophyllus is primarily distributed in peninsular Thailand and Malaysia, as well as Borneo, Sumatra, and Java in Indonesia. Its habitat is primary and secondary dry or wet disturbed forests with loamy clay or sandy soils over granite, and it is found at elevations of $0-1300 \mathrm{~m}$. G. macrophyllus is the most widespread species of the genus and is characterized by a medium-sized stem and tapered leaf tips. The leaves are $40-55 \mathrm{~cm}$ in length and $7-15 \mathrm{~cm}$ in width and are highly aromatic, as are the stems. This species is used widely by humans for medicinal purposes. Applications include the use of its leaves as a natural insecticide (van Valkenburg and Bunyapraphatsara 2002), Alabsi, et al. (2013) suggested that the natural extract of G. macrophyllus has anti-cancer properties against tumor cells, and an antidote for snake bites in the Serampas area of Jambi, Indonesia (Hariyadi and Ticktin 2012). Traditional healers in Patthalung Province, Thailand, use this species to treat flatulence, general fatigue, and body pain (Maneenoon et al. 2015). It is also used for anti-aging purposes (Ong et al. 2012) and as a treatment for typhoid fever (Setyowati and Wardah 2010). Pounded leaves and bark are used to treat skin complaints (Chong et al. 2012), and essential oil produced from the twigs and roots has shown strong antimicrobial properties against intermediately vancomycin-resistant Staphylococcus aureus, Staphylococcus epidermidis, and Candida albicans (Humeirah et al. 2010).

Balunas and Kinghorn (2005) reported that the increases in the medicinal uses of this species have increased its risk of extirpation or extinction in the wild. Many medicinal plant species are threatened with extinction from overharvesting and habitat destruction, and $20 \%$ of wild medicinal plant resources have already been 
lost due to overconsumption and anthropogenic activities (Zerabruk and Yirga 2012). Intrinsic biological factors and habitat loss are the major causes of plant endangerment in Indonesia, followed by overexploitation and natural factors (Budiharta et al. 2011). Raw materials have been harvested from G. macrophyllus for centuries by many indigenous groups, in particular, its bark is highly valued due to its chemical composition and unusual structure. However, the process of harvesting the bark can cause tree death, leading to population decline.

Natural regeneration of tree species is crucial to maintain its population and forest stand composition over space and time (Henle et al. 2004). Forest managers and ecologists must understand the processes driving forest species regeneration (Slik et al. 2003) because floristic and structural compositions vary among communities and intraor inter-species competition may relate to changes in regeneration opportunity for a given species (Barker and Kirkpatrick 1994). Studies of the population dynamics of tree seedlings in different forest stands have demonstrated that growth and survival are influenced by a variety of microclimatic and edaphic factors (Scholl and Taylor 2006).

Several regional taxonomic studies of Goniothalamus have been published for western Malesia, include-ing Peninsular Malaysia (Sinclair 1955), Java (Backer and Bakhuizen van den Brink 1963), and Borneo (Mat-Salleh 2001), and within the Gunung Lumut Protected Forest of
East Kalimantan (Slik et al. 2007). Research has been conducted to reveal the growth rates of seedlings, saplings, and poles of this species in the Masigit Mountain Kareumbi Forest, Sumedang District, West Java (Suwandhi 2009). We expand this existing knowledge by investigating population structure of the species, habitat preference, and environmental factors that influence local density of $G$. macrophyllus in Bukit Pembarisan forest, Kuningan District, West Java. The results of this study can serve as baseline information in developing conservation approaches.

\section{MATERIALS AND METHODS}

\section{Study period and area}

This research was conducted from September 2017 to March 2018 in specially protected forest Bukit Pembarisan in Kuningan District, West Java, Indonesia (Figure 1). The forest is located at $108^{\circ} 23^{\prime}-108^{\circ} 47^{\prime} \mathrm{E}, 6^{\circ} 47^{\prime}-7^{\circ} 12^{\prime} \mathrm{S}$ and includes nine villages: Pinara, Gunung Manik, Subang, Bagawat, Jatisari, Legokherang, Bungurberes, Mandapajaya, and Jabranti. The study area has type B and C climates (Schmidt and Ferguson 1952) with an average rainfall of 2,000-4,000 $\mathrm{mm} /$ year. During the study period, monthly average temperatures ranged from $18^{\circ} \mathrm{C}$ to $22^{\circ} \mathrm{C}$.
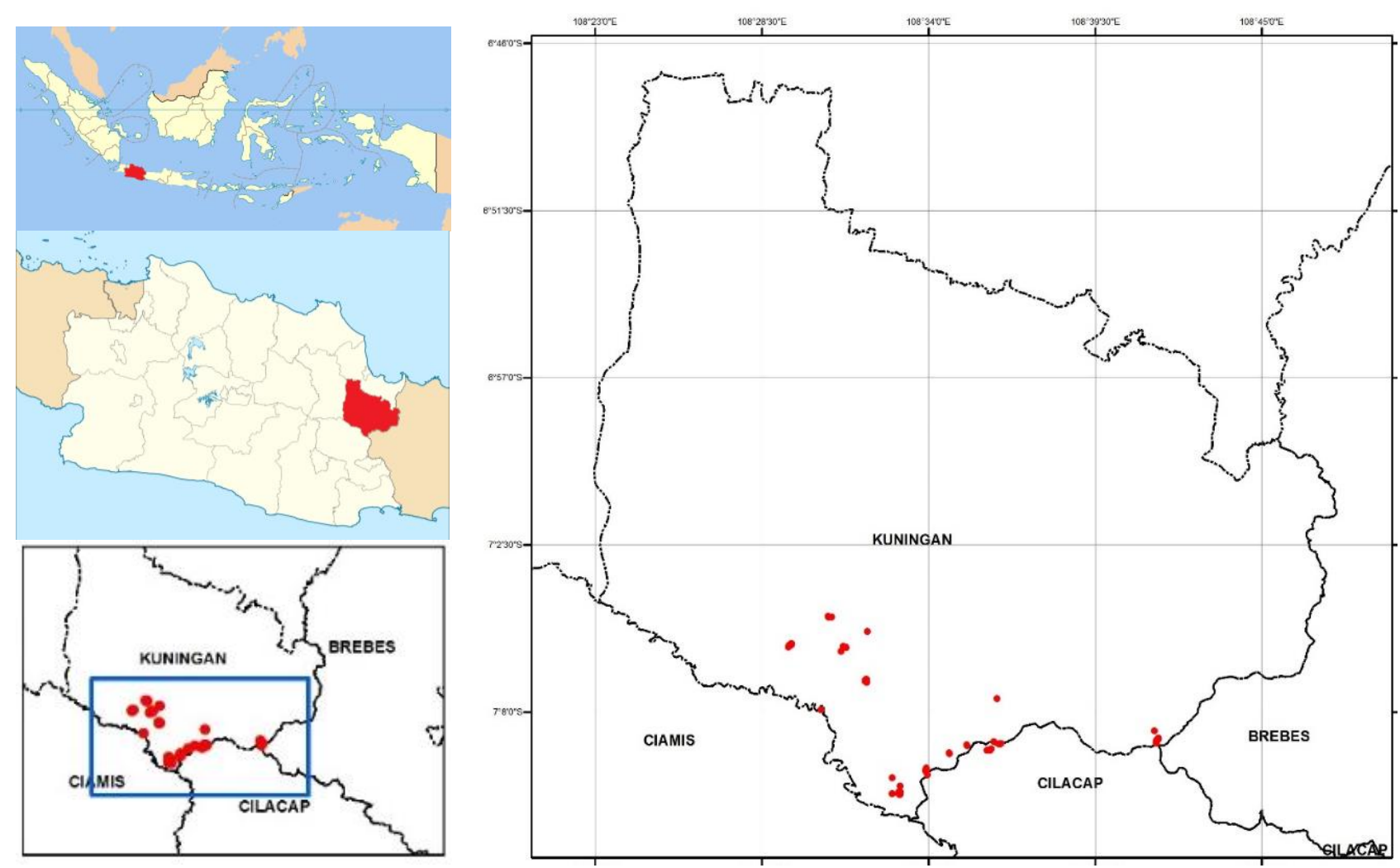

Figure 1. Study area and seventeen sampling sites of Goniothalamus macrophyllus in Bukit Pembarisan, Kuningan District, West Java, Indonesia 


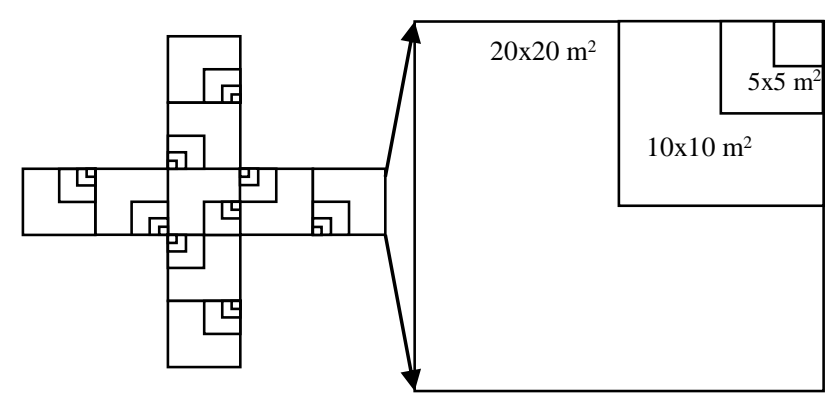

Figure 2. Nested survey plots used to assess G. macrophyllus at different growth stages

\section{Sampling procedure}

Sampling was conducted at seventeen sites based on the occurrence of $G$. macrophyllus found during the preliminary survey. These sites have altitudes ranging from $432 \mathrm{~m}$ asl to $1273 \mathrm{~m}$ asl. At each sampling location, nine plots were established, totaling 153 plots across the studied areas. Survey locations were determined using a purposive sampling method and conducted using the distance sampling technique (Burnham et al. 1980). Population structure of G. macrophyllus and soil data were taken using nested sample plot. Nine nested sample plots of varying sizes were established around G. macrophyllus populations to record individuals at varying growth stages (Kusmana 1997). Plot sizes included $2 \times 2 \mathrm{~m}^{2}$ plots for seedlings (< $1.5 \mathrm{~m}$ in height), $5 \times 5 \mathrm{~m}^{2}$ plots for saplings $(>1.5 \mathrm{~m}$ in height and $<10 \mathrm{~cm}$ in diameter), $10 \times 10 \mathrm{~m}^{2}$ plots for poles $\left(10-19 \mathrm{~cm}\right.$ in diameter), and $20 \times 20 \mathrm{~m}^{2}$ plots for trees (> $20 \mathrm{~cm}$ in diameter) (Figure 2). The number of individuals of each growth stage at each plot was recorded. Elevation was determined at each site.

Plant identification was done at the Herbarium Bogoriense, Indonesian Institute of Sciences in Bogor, Indonesia. Soil samples were taken from plots at $0-30 \mathrm{~cm}$ and $30-45 \mathrm{~cm}$ depths using a ground drill. Samples were then composited for each depth and analyzed at the Balitro Bogor Laboratory for physical characteristics (soil texture) and chemical properties ( $\mathrm{pH}$, organic carbon [OC], carbon: nitrogen ratio $[\mathrm{C} / \mathrm{N}]$, total nitrogen $(\mathrm{TN})$, phosphorus $[\mathrm{P}]$, potassium $[\mathrm{K}]$, calcium $[\mathrm{Ca}]$, and magnesium $[\mathrm{Mg}]$ ).

\section{Data analysis}

Data were analyzed using multiple linear regression with a stepwise approach with population density as response variable and environmental factors as predictor variables. Plot data of seedling, sapling, and pole counts were assessed using the following formula (Kusmana 1997):

$$
\mathrm{K}=\frac{\text { the number of type } \mathrm{i} \text { tree }(\mathrm{s})}{\text { plot size (ha) }}
$$

Where, $\mathrm{K}$ is the density of growth stage $i$ (seedling, sapling, and pole).

\section{RESULTS AND DISCUSSION}

\section{Population structure of Goniothalamus macrophyllus}

We encountered 46,279 individuals of G. macrophyllus across all sampling sites. However, most individuals were seedlings $(44,168$, equal to $94 \%$ of the total population), while saplings accounted for only $4 \%$ and poles accounted for only $0,1 \%$ (Figure 3), another study in New Medonia found population of $G$. dumontetii is 250 individuals, with a density of 1 individual per $200 \mathrm{~m}$ square (Saunder and Munzinger 2007). Other studies have also demonstrated that seedlings are the most common growth stage relative to saplings, poles, and trees for G. macrophyllus (Fathia 2016), and this age structure pattern in common in plants. Also, it is important to note the very low proportion of poles relative to seedlings and saplings in which among all sampling sites, poles were only detected at two locations, one at $997 \mathrm{~m}$ in elevation and the other at 1,175 $\mathrm{m}$ (Table 1). This was likely the result of limiting environmental factors. Laughlin and Clarkson (2018) suggested that death at the seedling stage is likely related to canopy cover.

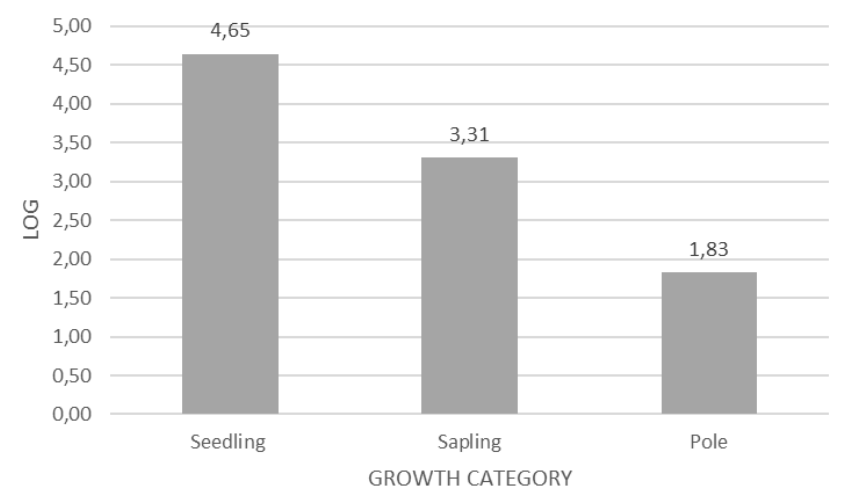

Figure 3. Population of Goniothalamus macrophyllus based on growth category

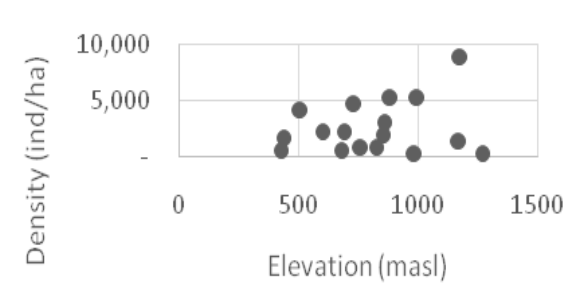

A

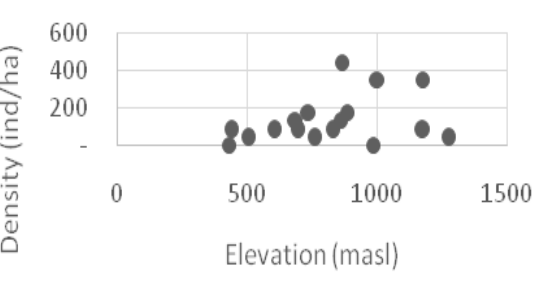

B

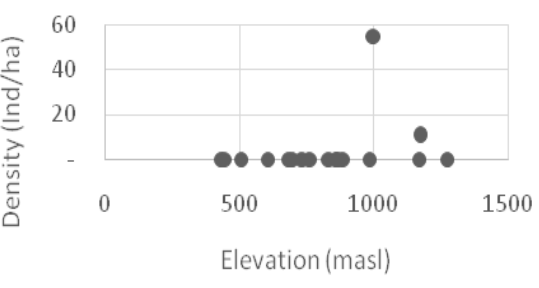

C

Figure 4. Goniothalamus macrophyllus densities among growth classes along an elevational gradient. A. Seedling, B. Sapling, C. Pole 
Goniothalamus macrophyllus population was observed at sites $432-1,273 \mathrm{~m}$ in elevation within the study area. This is consistent with the findings of Saunder and Munzinger (2007), who reported population of $G$. dumontetii grows in a level area $500 \mathrm{~m}$, in humid forest over ultramafic soil in New Caledonia. Other studies have also documented this species in low elevation forests $(<200$ m) (Fiqa et al. 2019; Susiarti et al. 2018). In terms of forest type, G. macrophyllus has been reported found in primary and secondary forests in Jambi (Hariyadi and Ticktin 2012). Moreover, Purnomo et al. (2015) found seedlings of G. macrophyllus growing in burnt forest areas in East Kalimantan. Based on these results, it can be indicated that G. macrophyllus inhabits primary and secondary lowland forests.

Among all sites, the highest density of seedlings was found at $1,175 \mathrm{~m}$ in elevation $(8,889$ individuals [ind]/ha), whereas the highest densities of saplings and poles were found at $864 \mathrm{~m} \mathrm{(444} \mathrm{ind/ha)} \mathrm{and} 997 \mathrm{~m} \mathrm{(56} \mathrm{ind/ha),}$ respectively. The lowest seedling density was observed at $1,273 \mathrm{~m}$ (278 ind/ha), and the lowest sapling and pole densities at 506-1,273 $\mathrm{m}$ (44 ind/ha) and 1,175 m (11 $\mathrm{ind} / \mathrm{ha}$ ), respectively (Table 1 ). During the sampling there was no tree stage were found in any sampling locations, however, the observed high densities of seedlings and saplings indicate that the lowland forest of the study site is suitable habitat for the species. The densities of poles and trees were low relative to other studies, but were high in terms of saplings and seedlings. Prasaja (2016) reported the densities of poles and trees of G. macrophyllus in Bukit Duabelas Jambi National Park, Indonesia with 215 ind/ha and $5 \mathrm{ind} / \mathrm{ha}$, respectively, while Handayani (2010) reported densities of $1 \mathrm{ind} / 5 \mathrm{ha}, 7 \mathrm{ind} / 5 \mathrm{ha}$, and $2 \mathrm{ind} / 5$ ha for seedlings, saplings, and poles, respectively. Elevation affected sapling density $(\chi 2=25.903, \mathrm{p}=0.055)$, but not pole $(\chi 2=44.310, p=0.000)$ or seedling $(f=0.004, p=1)$ density. However, we note that poles were only encountered at two locations.

\section{Habitat characteristics of Goniothalamus macrophyllus}

Temperature and humidity may strongly affect $G$. macrophyllus growth. G. macrophyllus occurred at temperatures of $19-25^{\circ} \mathrm{C}$ and relative humidity of $80-90 \%$. These values are comparable to those reported by Hanum (1999), who found G. macrophyllus in areas with 87.697.8\% humidity in Ayam Hutan Forest, and by Prasaja (2016), who reported humidity of $80-94 \%$ at $G$. macrophyllus locations in Bukit Duabelas Jambi National Park. Lestari and Sulistyadi (2015) reported that $G$. macrophyllus was found in areas with temperatures of $22.5-33^{\circ} \mathrm{C}$. In addition, this species is grown at the Bogor Botanical Gardens at temperatures of $25-39^{\circ} \mathrm{C}$ and humidity of 34-80\% (Handayani 2010). Table 2 describes the physical and chemical soil properties at $G$. macrophyllus sites.

Broadly, the results of the soil analysis suggested that this species prefers soils that are relatively acidic, with moderate to high $\mathrm{OC}$, moderate $\mathrm{TN}$, a low to moderate
$\mathrm{C} / \mathrm{N}$, very low $\mathrm{P}_{2} \mathrm{O}_{5}$, high to very high $\mathrm{Ca}$, and high $\mathrm{Mg}$ and K. Preferred soil textures appear to be sandy loams to sandy clay loams in which in accordance to Hanum (1999) who also reported $G$. macrophyllus growing on sandy clay loams in peninsular Malaysia. In summary, this species appears to grow in slightly acidic soils with sufficient macro- and micro-nutrient concentrations, which are common requirements by most plants for survival. The balance of nitrogen and phosphorus in plant tissues is of particular interest because this elementsplay a pivotal role in many aspects of plant biology and their availability frequently limits plant growth (Vitousek 1982; Chapin et al 1986; Gu Sewell 2004), P is important for strengthening stems and increasing disease resistance (Hardjowigeno 2007), and $\mathrm{Mg}$ is important for chlorophyll formation (Hardjowigeno 2007).

\section{Relationship between environmental factors and Goniothalamus macrophyllus density}

The results of multiple linear regression using a stepwise approach indicated that pole density was affected by soil clay content at the $0-30 \mathrm{~cm}$ soil depth $(\mathrm{t}=2.40, \mathrm{p}=$ $0.03, \mathrm{R}^{2}=0.278$ ), as well as by the clay content at the 30 $45 \mathrm{~cm}$ soil depth $(\mathrm{t}=2.578 \mathrm{p}=0.021)$. These results indicate that G. macrophyllus likely grows best in soils with a dominant clay content. Soil structure influences plant growth with regard to root distribution and the ability of the soil to absorb water and nutrient (Rampazzo, et al., 1998; Pardo, et al. 2000). Sandy soil surface disturbances resulted greatly decreased soil resistance to wind erosion (Zhang et al 2006), researchers are studying the role of microbiotic crusts on the structural stability of sandy soils (Belnap and Gardner, 1993; Verrecchia et al.,1995; Issa et al. 2001; Li et al. 2002). Hardjowigeno (2007) also emphasized that sandy soils tend to have lower nutrient concentrations than clay soils.

At a soil depth of $30-45 \mathrm{~cm}$, seedling density was affected by $\mathrm{TN}(\mathrm{t}=4.28, \mathrm{p}=0.01)$ and $\mathrm{pH}(\mathrm{t}=3.138, \mathrm{p}=$ $0.07)$. These results suggest that seedlings may perform best in soils with a high $\mathrm{N}$ concentration and neutral $\mathrm{pH}$. $\mathrm{N}$ is a critical nutrient for plants and a deficiency in this element can limit plant growth and lead to plant death (Hardjowigeno 2007). Nitrogen fertilizer application to cereal has achieved large increases in yields (Raun and Johnson 1999). Therefore adequate $\mathrm{N}$ is critical for normal plant growth (Wang et al. 2007; Homer 2008). Boussadia et al. (2010) reported that nitrogen deficiency in olive plants led to a reduction of leaf chlorophyll content and the rate of photosynthesis. Soil pH affects nutrient absorption by plants in which nutrients are more easily absorbed in soils with neutral pH (Hardjowigeno 2007).

In conclusion, G. macrophyllus appears to grow in habitats with average temperatures of $19-25^{\circ} \mathrm{C}$ and high humidity (80-90\%), in soils that are slightly acidic, have high to very high $\mathrm{Ca}, \mathrm{Mg}$, and $\mathrm{K}$ concentrations, low $\mathrm{P}$ concentrations, a low $\mathrm{C} / \mathrm{N}$, moderate $\mathrm{N}$ concentration, and a sandy clay loam texture. 
Table 2. Physical and chemical soil properties at two soil depths at Goniothalamus macrophyllus sampling locations

\begin{tabular}{|c|c|c|c|c|c|c|}
\hline \multirow{3}{*}{ Parameter } & \multicolumn{6}{|c|}{ Soil depth } \\
\hline & \multicolumn{3}{|c|}{$0-30 \mathrm{~cm}$} & \multicolumn{3}{|c|}{$30-45 \mathrm{~cm}$} \\
\hline & Range & Mean & Description & Range & Mean & Description \\
\hline $\mathrm{pH}$ & $4.61-6.28$ & 5.57 & Slightly acidic & $4.62-6.46$ & 5.63 & Slightly acidic \\
\hline $\mathrm{OC}(\%)$ & $0.23-8.84$ & 4.07 & High & $0.20-6.00$ & 2.39 & Moderate \\
\hline $\mathrm{TN}(\%)$ & $0.09-0.80$ & 0.39 & Moderate & $0.05-0.68$ & 0.25 & Moderate \\
\hline $\mathrm{C} / \mathrm{N}$ & $0.96-15.63$ & 9.58 & Low & $1.33-46.40$ & 11.24 & Moderate \\
\hline $\mathrm{P}_{2} \mathrm{O}_{5}(\mathrm{mg} / 100 \mathrm{~g})$ & $2.93-11.68$ & 4.29 & Very low & $2.69-13.94$ & 4.05 & Very low \\
\hline $\mathrm{Ca}(\mathrm{Cmol}(+) / \mathrm{Kg})$ & $1.43-34.22$ & 20.35 & Very high & $0.60-34.92$ & 16.79 & High \\
\hline $\operatorname{Mg}(\mathrm{Cmol}(+) / \mathrm{Kg})$ & $0.65-11.57$ & 5.84 & High & $1.18-10.47$ & 5.72 & High \\
\hline $\mathrm{K}(\mathrm{Cmol}(+) / \mathrm{Kg})$ & $0.07-3.13$ & 0.95 & High & $0.13-2.61$ & 0.68 & High \\
\hline Sand $(\%)$ & $37.20-80.08$ & 60.74 & Sandy loam & $17.14-74.71$ & 54.96 & Sandy clay loam \\
\hline Dust (\%) & $0.00-35.15$ & 11.60 & & $0.00-42.65$ & 16.93 & \\
\hline Clay $(\%)$ & $14.94-48.98$ & 27.68 & & $15.38-48.23$ & 28.60 & \\
\hline
\end{tabular}

Note: OC: Organic Carbon, TN: Total Nitrogen, C/N: Carbon Nitrogen ratio

\section{Conservation implications}

When considering conservation efforts for this species, it is important to give attention to the survival and growth of poles such that they can develop and produce seeds to ensure the sustainability of local populations. Silvertown et al (2006) suggested that high densities of a plant species within a habitat indicate suitable environmental conditions for that species. Various studies in tropical forests have related differences in tree densities to environmental variables such as light intensity (Yamada 2006), topography (Sri-Ngernyuang 2003), edaphic factors (Palmiotto 2006), or a combination of these factors (Davies et al. 2004). Our study indicated that seedling density was affected by $\mathrm{TN}$ and $\mathrm{pH}$, and pole density was affected by soil clay content. Our recommendations for future conservation efforts, based on these findings, include the maintenance of existing poles, a prohibition on bark harvesting, and encouraging use of the leaves, rather than bark, for medicinal applications among consumers of $G$. macrophyllus.

\section{ACKNOWLEDGEMENTS}

We express our gratitude to the Faculty of Biology at General Sudirman University, Purwokerto, banyumas, Indonesia, the Faculty of Forestry at the Kuningan University, Indonesia the Balitro Soil Laboratory, the Ministry of Agriculture of the Republic of Indonesia in Bogor, Indonesia and Perum Perhutani Regional Division III of West Java and Banten. We also convey our gratitude to Yayan Hendrayana, Agus Yadi Ismail, Alif, and many friends that have been steadfast in surveying and data collection.

\section{REFERENCES}

Alabsi AM, Ali R, Ali AM, Harun H, Al-Dubai SAR, Ganasegeran K, Alshagga MA, Salem SD, Hayati N. 2013. Induction of Caspase-9, Biochemical Assessment and Morphological Changes Caused by Apoptosis in Cancer Cells Treated with Goniothalamin Extracted from Goniothalamus macrophyllus. Asian Pac J Cancer Prevent 14 (11): 6273-6280.

Backer CA, Bakhnizen van den Brink RC. 1963. Flora of Java, Vol 1. Noordhoff, Groningen.

Balunas MJ, Kinghorn AD. 2005. Drug discovery from medicinal plants. Life Sci 78: 431-441.

Barker PCJ, Kirkpatrick JB. 1994. Phyllocladus aspleniifolius: Variability in the population structure, the regeneration niche and dispersion pattern in Tasmanian Forests. Austr J Bot 42 (2): 163-193.

Belnap J, Gardner JS. 1993. Soil microstructure in soil of the Colorado Plateau: the Role of the Cyanobacterium microcoleus O'aginatus. Great Basin Naturalis 53: 40-47

Boussadia O, Steppe K, Zgallai H, Ben El Hadj S, Braham M, Lemeu, R, Van Labeke MC. 2010. Effects of nitrogen deficiency on leaf photosynthesis, carbohydrate status and biomass production in two olive cultivars "Meski" and "Koroneiki". Sci Hortic 123: 336-342.

Budiharta S, Widyatmoko D, Irawati, Wiriadinata H, Rugayah, Partomihardjo T, Ismail, Uji T, Keim AP, Wilson K. 2011. The processes that threaten Indonesian plants. Oryx 45: 172-179.

Burnham KP, Anderson DR, Laake JL. 1980. Estimating density from line transect sampling of biological populations. Wildlife Monogr 72: 3202.

Chapin, FS, PM Vitoesek, K Vancleve. 1986. The nature of nutrient limitation in plant communities. Amer Nat 127: 48-58

Chong AP, Markus A, Rossall S. 2012. The susceptibility of different varieties of oil palm seedling to Gonederma boninense infection. Pak J Bot 44 (6): 2001-2004.

Davies SJ, Tan S, LaFrankie JV, Potts MD. 2005. Soil-related floristic variation in the hyperdiverse dipterocarp forest in Lambir Hills, Sarawak. In: Roubik DW, Sakai S, Hamid A (eds.) Pollination Ecology and Rain Forest Diversity. Sarawak Studies, SpringerVerlag, Berlin.

Fathia AA. 2016. Komposisi Jenis dan Struktur Tegakan Serta Kualitas Tanah di Hutan Gunung Galunggung Tasikmalaya [Hon Thesis]. Institut Pertanian Bogor, Bogor. [Indonesian]

Fiqa AP, Fauziah, Lestari DA, Budiharta S. 2019. The importance of insitu conservation area in mining concession in preserving diversity, threatened and potential floras in East Kalimantan, Indonesia. Biodiversitas 20: 198-210.

Gu Sewell S. 2004. N : P Ratio in terrestrial Plant: Variation and Functional Significance. New Phytol 164: 243-266

Handayani FM. 2010. Kajian Permudaan Tumbuhan Langka Kulim (Scorodocarpus borneensis Becc.) dan Komposisi Vegetasi Pohon Sekitarnya di Taman Nasional Tesso Nilo, Riau. [Hon. Thesis]. Institut Pertanian Bogor, Bogor, Indonesia. [Indonesian]

Hanum F. 1999. Plant diversity and conservation value of Ayer Hitam Forest, Selangor, Peninsular Malaysia. Pertanika J Trop Agric Sci 22: 73-83.

Hardjowigeno S. 2007. Ilmu Tanah. Akademika Pressindo, Jakarta, Indonesia. [Indonesian] 
Hariyadi B, Ticktin T. 2012. Uras: medicinal and ritual plants of Serampas, Jambi Indonesia. Ethnobot Res Appl 10: 133-149.

Henle K, Davies KF, Kleyer M, Margules C, Settele J. 2004. Predictors of Spesies Sensitivity to Fragmentation. Biodiv Conserv 13: 207-251.

Homer ER. 2008. The Effect of Nitrogen Application Timing on Plant Available Phosphorus. [Thesis]. The Ohio State University, USA.

Huber H. 1985. Annonaceae In: Dassanayake MD (ed), A revised handbook to the Flora of Ceylon Vol. 5. A.A. Balkema, Rotterdam.

Humeirah AGS, Nor Azah MA, Mastura M, Milina J, Saiful JA, Muhajir H, Puad AM. 2010. Chemical constituents and antimicrobial activity of Goniothalamus macrophyllus (Annonaceae) from Pasoh Forest Reserve, Malaysia. Afr J Biotechnol 9: 5511-5515.

Issa OM, Bissonnais YL, Defarge C, Trichet J. 2001. Role of a cyanobacterial cover on structural stability of sandy soils in the Sahelian Part of Western Niger. Geoderma 101: 15-30

Jessup LW. 1986. The genus Goniothalamus (Blume) JD Hook. \& Thomson (Annonaceae in Australia. Austrobaileya 2(3): 224-226

Kusmana C. 1997. Metode Survey Vegetasi. PT. Penerbit Institut Pertanian Bogor, Bogor, Indonesia. [Indonesian]

Laughlin DC, Clarkson BD. 2018. Tree seedling survival depends on canopy age, cover and initial composition: Trade-offs in forest restoration enrichment planting. Ecol Rest 36: 52-61.

Lestari D, Sulistyadi E. 2015. Preliminary study of species area curve in Dungus Iwul Nature Reserve, Jasinga, Bogor. The 5th Internationa Conference on Plant Diversity (ICPD 2015) Plant Diversity: A Global Challenge. Universitas Jenderal Soedirman, Purwokerto, Indonesia. 158-162. [Indonesian]

Li XR, Wang XP, Li T. 2002. Microbiotic soil crust and its effect on vegetation and habitat on artificially stabilized desert dunes in Tengger Desert, Northern China. Biol Fert Soils 35: 147-154

Maneenoon K, Khuniad C, Teanuan Y, Saedan N, Prom-in S, Rukleng N, Kongpool W, Pinsook P, Wongwiwat W. 2015. Ethnomedicinal plants used by traditional healers in Phatthalung Province, Peninsular Thailand. J Ethnobiol Ethnomed 11: 1-20.

Mat-Salleh K. 2001 New and Noteworthy Species of Bornean Goniothalamus (Annonaceae). Folia Malaysiana 2: 75-116

Mitra D. 1997. Annonaceae In: Sharma BD. et al. (eds), Flora of India. Vol. 1. Botanical Survey of India, Calcutta, India.

Nakkunthod M, Su YC, Seelanan T, Saunders RMK. 2009. Molecular phylogenetic and morphological evidence for the congeneric status of Goniothalamus and Richella (Annonaceae). Taxon 58 (1): 127-132.

Ong HC, Faezah AW, Milow P. 2012. Medicinal plants used by the Jah Hut Orang Asli at Kampung Pos Penderas, Pahang, Malaysia. Ethno Med 1: 11-15.

Palmiotto PA, Davies SJ, Vogt KA, Ashton MS, Vogt DJ, Ashton PS 2004. Soil-related habitat specialization in dipterocarp rain forest tree species in Borneo. J Ecol 92: 609-623.

Pardo A, Amato M, Chiaranda FQ. 2000. Relationships between soil structure, root distribution and water uptake of chickpea (Cicer arietinum L.). plant growth and water distribution. Eur J Agron 13 $39-45$.

Prasaja D. 2016. Bioekologi dan Etnobotani Pandan (Pandanaceae) oleh Orang Rimba di Taman Nasional Bukit Duabelas Jambi. PT. Penerbit Institut Pertanian Bogor, Bogor, Indonesia. [Indonesian]

Purnomo SH, Bratawinata A, Simarangkir BDAS, Matius P. 2015 Vegetation diversity in the high-severity burned over forest areas in East Kalimantan, Indonesia. Acad J Agric Res 3: 213-221.

Rampazzo N, Blum WEH, Wimmer B. 1998. Assessment of soil structure parameters and functions in agricultural soils. Bodenkultur 49: 69-84.

Raun WR, Johnson GV. 1999. Improving nitrogen use efficiency for cereal production. Agron J 91: 357-363

Saunder RMK. 2002. The genus Goniothalamus (Annonaceae) in Sumatra. Bot J Linn Soc 139: 225-254

Saunders RMK, Chalermglin P. 2008. A synopsis of Goniothalamus species (Annonaceae) in Thailand, with description of three new species. Bot J Linn Soc 156: 355-384

Saunders RMK. 2003. A synopsis of Goniothalamus species (Annonaceae) in Peninsular Malaysia, with a description of a new species. Bot J Linn Soc 142: 321-339.
Saunders, RMK, Munzinger JA. 2007. New species of Goniothalamus (Annonaceae) from New Caledonia, representing a significant range extension for the genus. Bot J Linn Soc 155: 497-503.

Schmidt FH, Ferguson JH. 1952. Rainfall types based on wet and dry period ratios for Indonesia with Western New Guinea. Verhand No. 42. Kementerian Perhubungan Djawatan Meteorologi dan Geofisika. Jakarta.

Scholl, A, Taylor, AH. 2006. Regeneration pattern in old growth red firwestern white pine forest in the Northern Siera Nevada, Lake Tahoe, USA. For Ecol Manag 235: 143-154.

Setyowati FM, Wardah. 2010. Utilization of traditional medicine as stamina enhancer in Sundanese communities at Cicemet Village, Banten Kidul; Proceedings of International Conference on Medicinal Plants. Surabaya, 21-21 July 2010. [Indonesian]

Silvertown, J, Dodd M, Gowing D, Lawson C, McConway K. 2006. Phylogeny and the hierarchical organization of plant diversity. Ecology 87 (Suppl): 39-49.

Sinclair J, 1955. A Revision of the Malayan Annonaceae. Gard Bull Sing 14: $149-508$

Slik JWF, Hovenkamp P, Iqbal M, Raes N. 2007. Structure, plant species diversity and plant species composition of the Gunung Lumut Protection Forest (East Kalimantan, Indonesia). National Herbarium Nederland, Leiden University Branch, Leiden.

Slik JWF, Poulsen AD, Ashton PS, Cannon CH, Eichhorn KAO, Kartawinata K, Lanniari I, Nagamasu H, Nakagawa M, van Nieuwstadt MGL, Payne J, Purwaningsih, Saridan A, Sidiyasa K, Verburg RW, Webb CO, Wilkie P. 2003. A floristic analysis of the lowland dipterocarp forests of Borneo. J Biogeogr 30: 1517-1531.

Sri-Ngernyuang K, Kanzaki M, Mizuno T, Noguchi H, Teejuntuk S, Sungpalee C, et al. 2003. Habitat differentiation of Lauraceaespecies in a tropical lower montane Forest in northern Thailand. Ecol Res 18: $1-14$.

Susiarti S, Rahayu M, Rugayah. 2018. Diversity of Indonesian Medicinal Plant in The lowland Forest, Bodogol and Its Surrounding of Mount GedePangrango National Park, West Jawa. IOP Conf. Ser Earth Environ Sci 166: 1-13.

Suwandhi I. 2009. Kenormalan struktur dan komposisi tegakan hutan alam Gunung Kareumbi Masigit Kabupaten Sumedang Jawa Barat. Wana Mukti For Res J 9: 49-56.

Tang CC, Xue B, Saunders RMK. 2013. A New Species of Goniothalamus (Annonaceae) from Palawan, and new Nomenclatural Combination in the genus from Fiji. Phytokes 32: 27-35.

Turner IM, Saunders RMK. 2008. Four new species of Goniothalamus (Annonaceae) from Borneo. Nordic J Bot 26: 329-337.

Van Valkenburg JLCH, Bunyapraphatsara N (eds). 2002. Plant Resources of Southeast Asia; 2. Medicinal \& Poisonous Plants. PROSEA, Bogor, Indonesia

Verrecchia E, Yair A, Kidron GJ, Verrecchia K, 1995. Physical Properties of the psammophile microbiotic crust and their consequences to the water regime of sandy soil, North-Western Negev Desert, Israel. J Arid Environ 29: 427-437

Vitousek P. 1982. Nutrient Cycling and Nutrient Use Efficiency. Amer Nat 119: 553-572.

Wang YP, Houlton BZ, Field CB. 2007. A model of biogeochemical cycles of carbon, nitrogen, and phosphorus including symbiotic nitrogen fixation and phosphatase production. Glob Biogeochem Cycles 21: 1018-1029.

Yamada T, Ngakan OP, Suzuki E. 2006. Differences in growth and light requirement of two sympatric congeneric tree species in an Indonesian floodplain forest. J Trop Ecol 22: 349-352.

Zerabruk S, Yirga G. 2012. Traditional knowledge of medicinal plants in Gindeberet district, Western Ethiopia. S Afr J Bot 78: 165-169.

Zhang YM, Wang HL, Wang XQ, Yang WK, Zhang DY. 2005. The microstructure of microbiotic crust and its influence on wind erosion for a sandy soil surface in the Gurbantunggut Desert of Northwestern China. Geoderma 132: 441-449. 